Military Technical College Kobry El-Kobbah, Cairo, Egypt

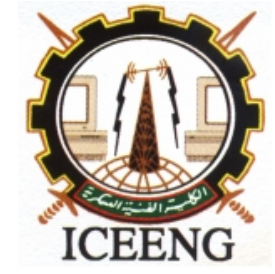

\author{
$7^{\text {th }}$ International Conference \\ on Electrical Engineering \\ ICEENG 2010
}

\title{
Comparison of Maximum Power Point Tracking Techniques for Different Types of Photovoltaic Models
}

\author{
By \\ Dr. Doaa khalil Ibrahim* Prof. Dr. Mohamed Mamdouh Abd-elaziz * Mina Badry Youwakim*
}

\section{$\underline{\text { Abstract: }}$}

Maximum power point tracking (MPPT) techniques are used in photovoltaic (PV) systems to maximize the PV array output power by tracking continuously the maximum power point (MPP) which depends on panel's temperature and on irradiance conditions. For low-cost implementations, four methods are introduced in this paper in a comparative study: Hill Climbing/the perturb and observe (P\&O), Incremental Conductance (IncCond), Fractional Open-Circuit Voltage and Fractional Short-Circuit Current maximum power point tracking algorithms. These are the most commonly used methods due their implementation ease.

In this paper, models of different types of photovoltaic such as Single-crystalline, Polycrystalline and Amorphous are implemented and compared based on their characteristics and their MPP tracking efficiency.

"MATLAB R2008a" facilities are used for simulation and modeling of different methods of MPPT tracking on different types of PV models mentioned above.

\section{Keywords:}

Maximum power point (MPP), maximum power point tracking (MPPT), perturb and observe (P\&O), photovoltaic (PV), Incremental Conductance (IncCond), MPP tracking efficiency.

* Faculty of Engineering, Cairo University, Cairo, Egypt 


\section{Introduction:}

A PV array is by nature a non-linear power source, which under constant uniform irradiance and cell temperature has a current-voltage (I-V) characteristic. There is a unique point on the curve, called the maximum power point (MPP), at which the array operates with maximum efficiency and produces maximum output power.

As it is well known, the MPP of a PV power generation system depends on array temperature, solar radiation, shading conditions and PV cells ageing, so it is necessary to constantly track the MPP of the solar array. A switch-mode power converter, called a maximum power point tracker (MPPT), can be used to maintain the PV array's operating point at the MPP. The MPPT does this by controlling the PV array's voltage or current independently of those of the load.

The issue of maximum power point tracking (MPPT) has been addressed in different ways as: Fuzzy Logic Control, Neural Network, RCC (Ripple Correlation Control), Current Sweep, DC-Link Capacitor Droop Control, Load Current or Load Voltage Maximization, dP/dV or dP/dI Feedback Control, Array Reconfiguration, Linear current control, IMPP and VMPP computation, State-based MPPT, One-cycle control (OCC) MPPT, The best fixed voltage(BFV), Linear reoriented coordinates method (LRCM), and Slide Control [1].

In this manuscript, Perturb and Observe ( $\mathrm{P} \& \mathrm{O})$, Incremental Conductance (IncCond), Fractional Open-Circuit Voltage and Fractional Short-Circuit Current techniques are compared because of their widely used, especially for low-cost implementations.

\section{Modeling of $P V$ :}

An equivalent circuit shown in Fig. 1 is used with the following set of circuit equations to express a typical (I-V) characteristic of PV modules [2]

$$
\begin{aligned}
& I=I_{p h}-I_{d}-I_{r} \\
& I_{p h}=I_{\text {sho }}\left(\frac{S}{1000}\right)+J_{o}\left(T-T_{\text {ref }}\right) \\
& I_{d}=I_{o}\left[\exp \left\{\frac{q\left(V+R_{s} I\right)}{n k T}\right\}-1\right] \\
& I_{o}=I_{d 0}\left(\frac{T}{T_{r e f}}\right)^{3} \exp \left\{\frac{q E_{g}}{n k}\left(\frac{1}{T_{\text {ref }}}-\frac{1}{T}\right)\right\} \\
& I_{r}=\frac{V+R_{s} I}{R_{\text {sh }}}
\end{aligned}
$$




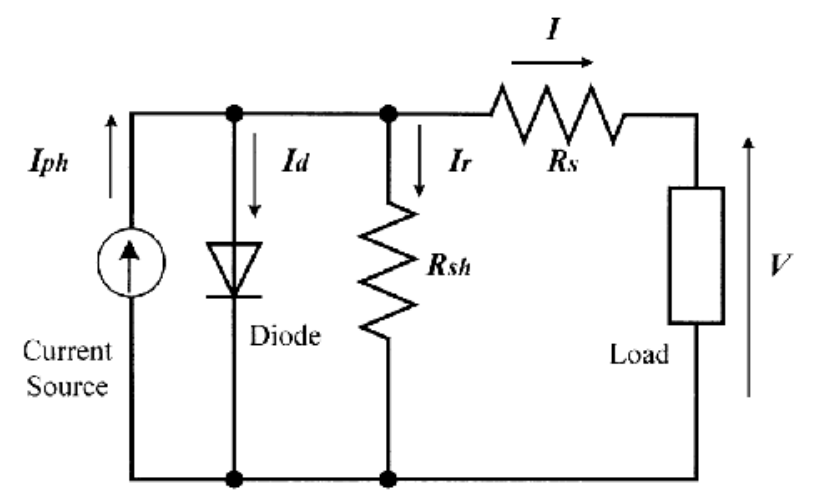

Figure (1): Equivalent circuit for PV modules

Where:

$\mathrm{S}$ is the solar insolation in $\mathrm{W} / \mathrm{m}^{2}, \mathrm{~T}_{\text {ref }}$ is the reference temperature $(298 \mathrm{~K})$, $\mathrm{T}$ is the cell temperature, $\mathrm{E}_{\mathrm{g}}$ is the band gap energy of the cell semiconductor, $\mathrm{k}$ is Boltzmann constant, $R_{s}$ is the series resistance, $R_{s h}$ is the shunt resistance, $n$ is the diode emission factor, $I_{\text {do }}$ is the diode reversal current, $I_{\text {sho }}$ is the short-circuit current at reference state and Jo is its temperature coefficient.

The parameters of three types (single-crystalline, polycrystalline and amorphous) PV modules are shown in Table 1 [2]. As given, there is a large difference in $R_{\mathrm{sh}}$ and $\mathrm{I}_{\mathrm{do}}$ among these modules. In amorphous module, both the diode reversal current $\mathrm{I}_{\mathrm{do}}$ and the diode emission factor $\mathrm{n}$ are larger than those of the crystalline modules.

Table (1): Equivalent circuit parameters of different types of $P V$ modules

\begin{tabular}{|c|c|c|c|}
\hline Type PV & Single-crystalline & Polycrystalline & Amorphous \\
\hline $\mathrm{R}_{\mathrm{s}}(\Omega)$ & 0.3464 & 0.3597 & 0.4204 \\
\hline $\mathrm{R}_{\mathrm{sh}}(\Omega)$ & 193.7 & 972.6 & 138.4 \\
\hline $\mathrm{n}$ & 49.53 & 46.6 & 104.95 \\
\hline $\mathrm{I}_{\mathrm{sho}}(\mathrm{A})$ & 4.784 & 4.443 & 2.459 \\
\hline $\mathrm{I}_{\mathrm{do}}(\mu \mathrm{A})$ & 0.2287 & 0.0711 & 467.36 \\
\hline $\mathrm{J}_{\mathrm{o}}(\mathrm{mA} / \mathrm{K})$ & 1.6 & 1.6 & 1.8 \\
\hline $\mathrm{E}_{\mathrm{g}}(\mathrm{V})$ & 45.08 & 45.12 & 44.79 \\
\hline
\end{tabular}

Using Newton-Raphson method, the characteristic of each type, the influence of temperature and solar radiation on each one and the influence of the series resistance are obtained. 


\subsection{Characteristics of Polycrystalline, Single-crystalline and Amorphous}

Figs. 2(a) and (b) give (I-V) and (P-V) characteristics of the three PV modules at same temperature and solar radiation $\left(\mathrm{S}=715.8 \mathrm{~W} / \mathrm{m}^{2}, \mathrm{~T}=50.1^{\circ} \mathrm{C}\right)$. As shown, singlecrystalline gives the highest power, polycrystalline have also a good performance but amorphous is the lowest one.

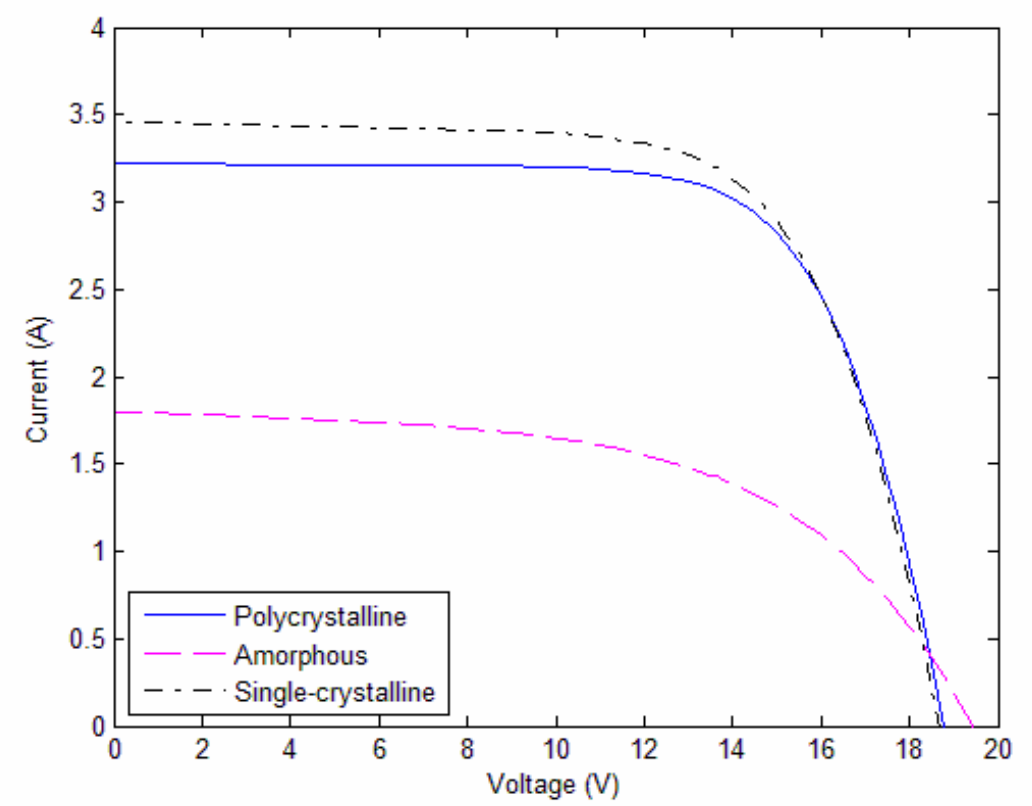

Figure (2a): (I-V) characteristics of polycrystalline, single-crystalline and amorphous.

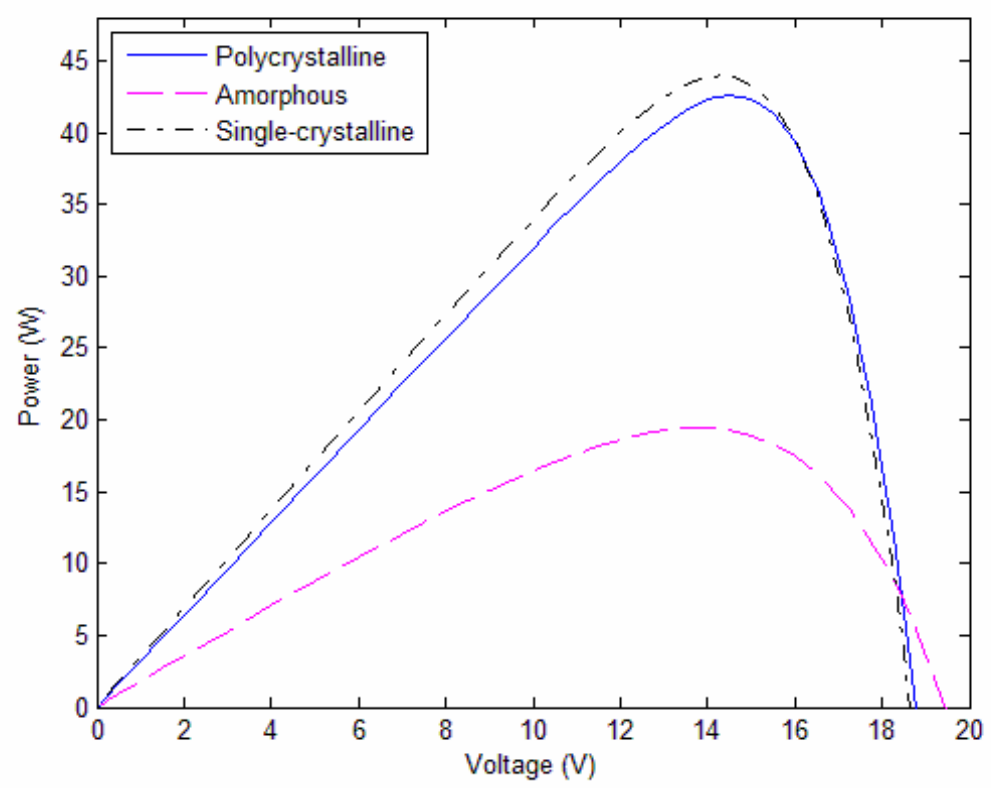

Figure (2b): $(P-V)$ characteristics of polycrystalline, single-crystalline and amorphous. 


\subsection{Influence of temperature, solar radiation and series resistance}

The effect of different values of solar radiation for single-crystalline type is shown in Fig. 3, while the effect of temperature changing for amorphous type is shown in Fig. 4. Simulating for series resistance varying is illustrated for polycrystalline type in Fig. 5.

As shown, the short circuit current is clearly proportional to solar radiation (Fig. 3(a)), and also more maximum output power (Fig. 3(b)).

On the other hand, the temperature dependence is inverse proportional (Fig. 4(a)); an increase in temperature causes a reduction of the open-circuit voltage (when sufficiently high) and hence also of the maximum output power (Fig. 4(b)). Therefore, these opposite effects of the variations of solar radiation and temperature on the maximum output power ensure tracking MPP efficiently is so essential.

The series resistance of the model has a large impact on the slope of the I-V curves at $\mathrm{V}_{\mathrm{OC}}$ as seen in Fig.5 [3].

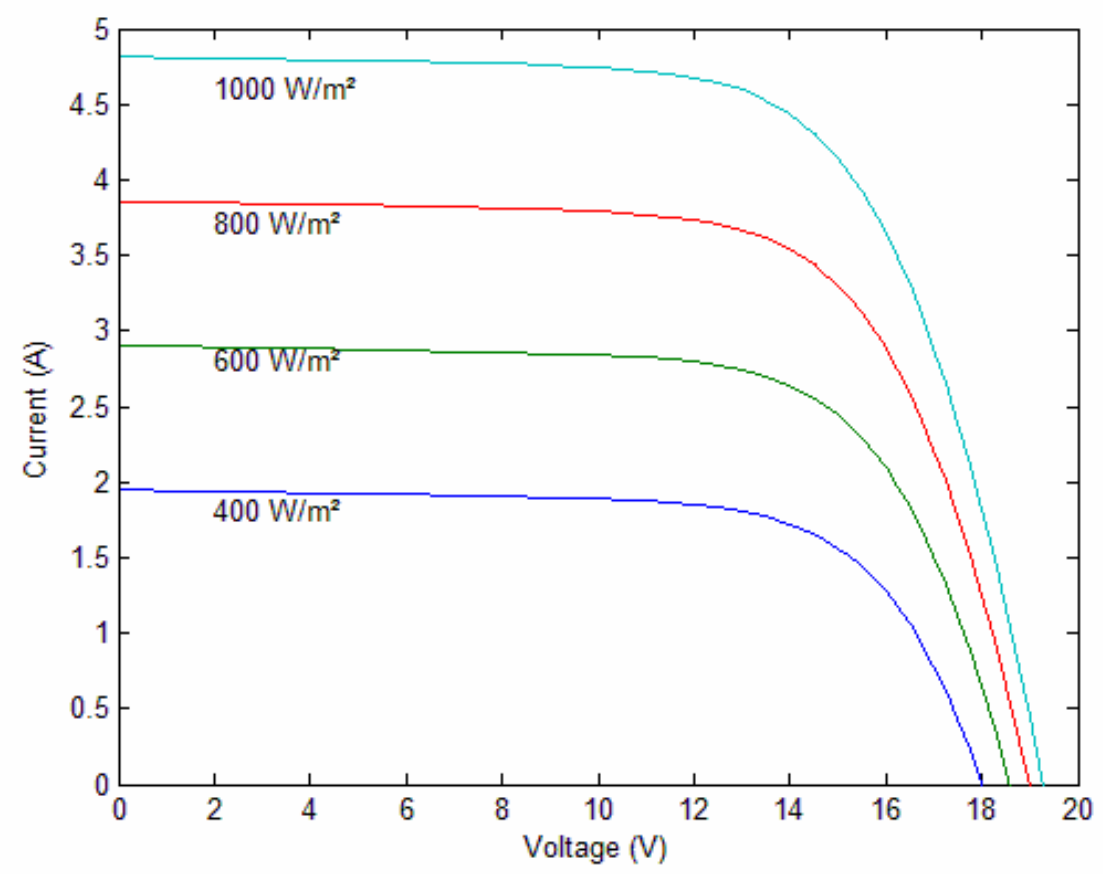

Figure (3a): I-V curves for various solar radiation of single-crystalline type $\left(T=48.3{ }^{\circ} \mathrm{C}, \mathrm{S}=400,600,800 \& 1000 \mathrm{~W} / \mathrm{m}^{2}\right)$ 


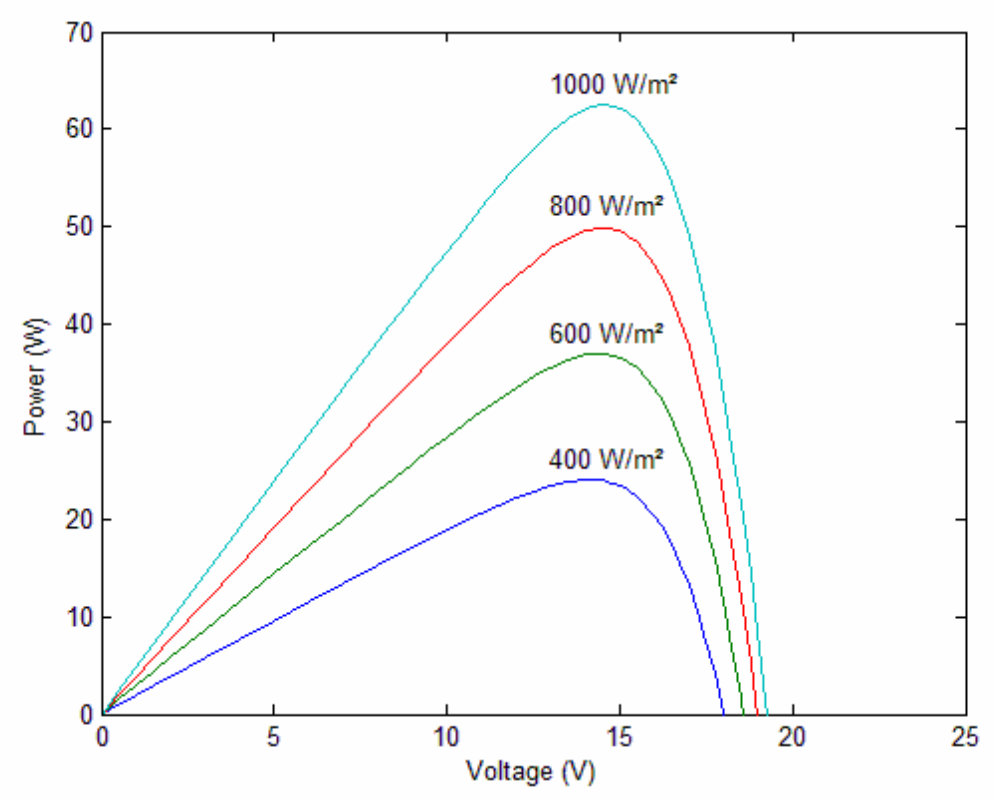

Figure (3b): $P-V$ curves for various solar radiation of single-crystalline type $\left(T=48.3{ }^{\circ} \mathrm{C}, S=400,600,800 \& 1000 \mathrm{~W} / \mathrm{m}^{2}\right)$

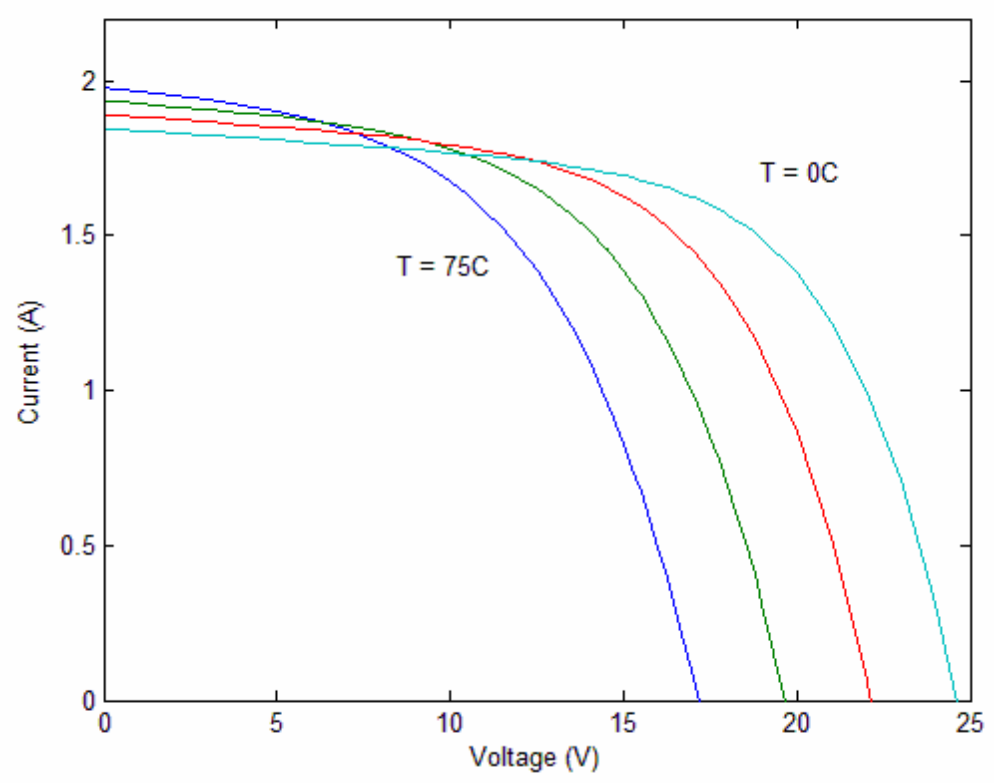

Figure (4a): I-V curves for various temperatures of the amorphous Type $\left(S=770.9 \mathrm{~W} / \mathrm{m} 2, T=0,25,50 \& 75^{\circ} \mathrm{C}\right)$ 


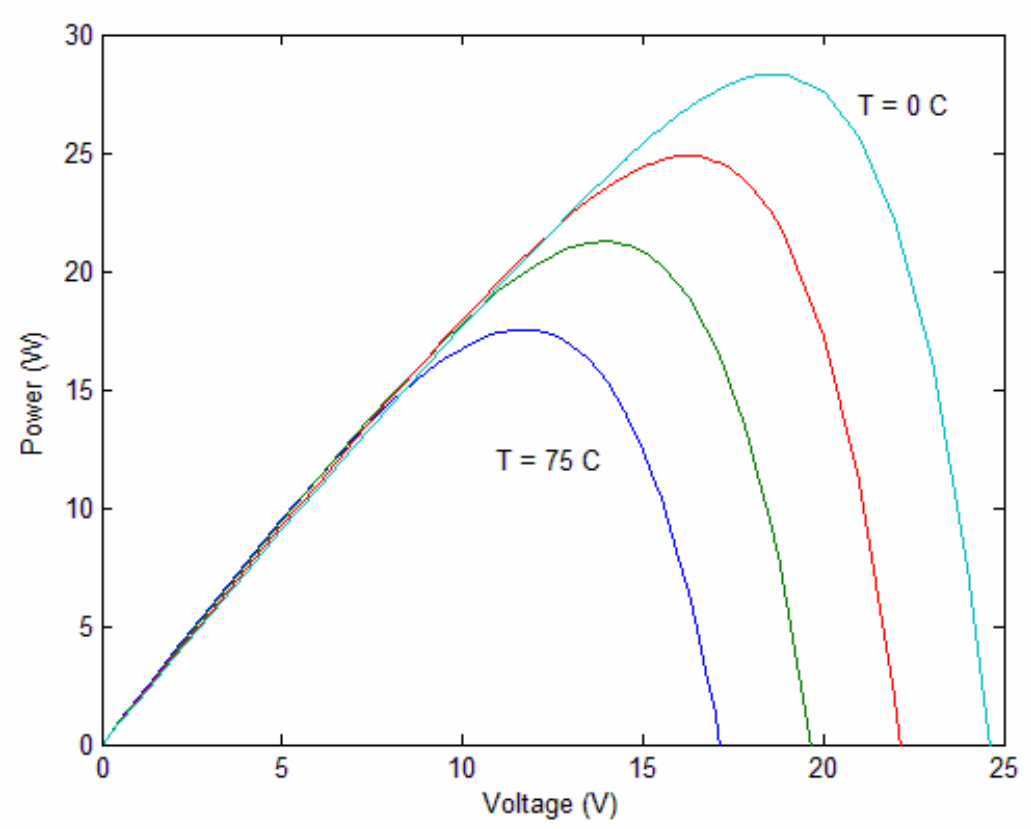

Figure (4b): $P$-V curves for various temperatures of the amorphous Type $\left(S=770.9 \mathrm{~W} / \mathrm{m} 2, T=0,25,50 \& 75^{\circ} \mathrm{C}\right)$

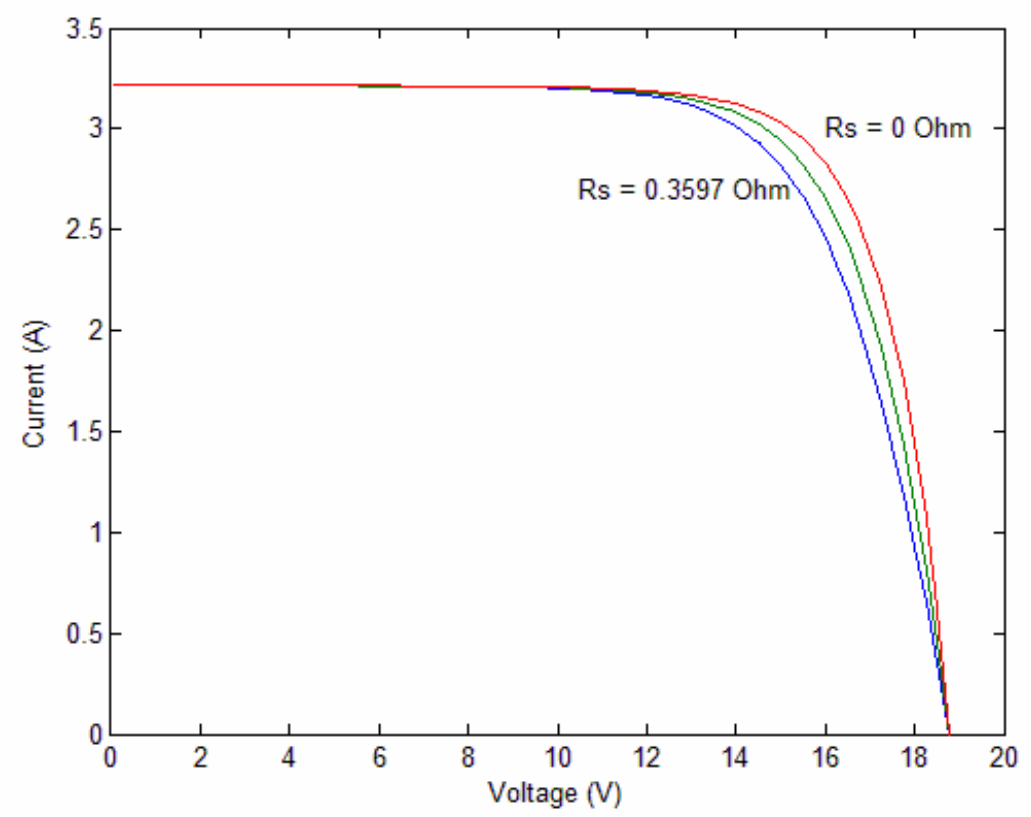

Figure (5): I-V curves of polycrystalline model for various series resistances ( $S=$ $715 \mathrm{~W} / \mathrm{m} 2, \mathrm{~T}=50.1^{\circ} \mathrm{C}, \mathrm{Rs}=0,179.85,359.7 \mathrm{~m}$ ) 


\section{How Maximum Power Point are obtained :}

MPPT is obtained by introducing a DC/DC converter in between the load and the solar PV module. The duty cycle of the converter is changed till the peak power point is obtained.

Considering a step down converter is used

$\mathrm{V}_{\mathrm{O}}=\mathrm{D} \times \mathrm{V}_{\mathrm{i}}$

( $\mathrm{V}_{\mathrm{O}}$ is output voltage and $\mathrm{V}_{\mathrm{i}}$ is input voltage)

Solving for the impedance transfer ratio

$\mathrm{R}_{\mathrm{O}}=\mathrm{D}^{2} \times \mathrm{R}_{\mathrm{i}}$

( $R_{\mathrm{O}}$ is output impedance and $\mathrm{R}_{\mathrm{i}}$ is input impedance as seen by the source.)

$\mathrm{Ri}=\mathrm{Ro} / \mathrm{D}^{2}$

Thus, output resistance $\mathrm{R}_{O}$ remains constant and by changing the duty cycle, the input resistance $\mathrm{R}_{\mathrm{i}}$ seen by the source changes. Therefore, the resistance corresponding to the peak power point is obtained by changing the duty cycle as shown in Fig.6.

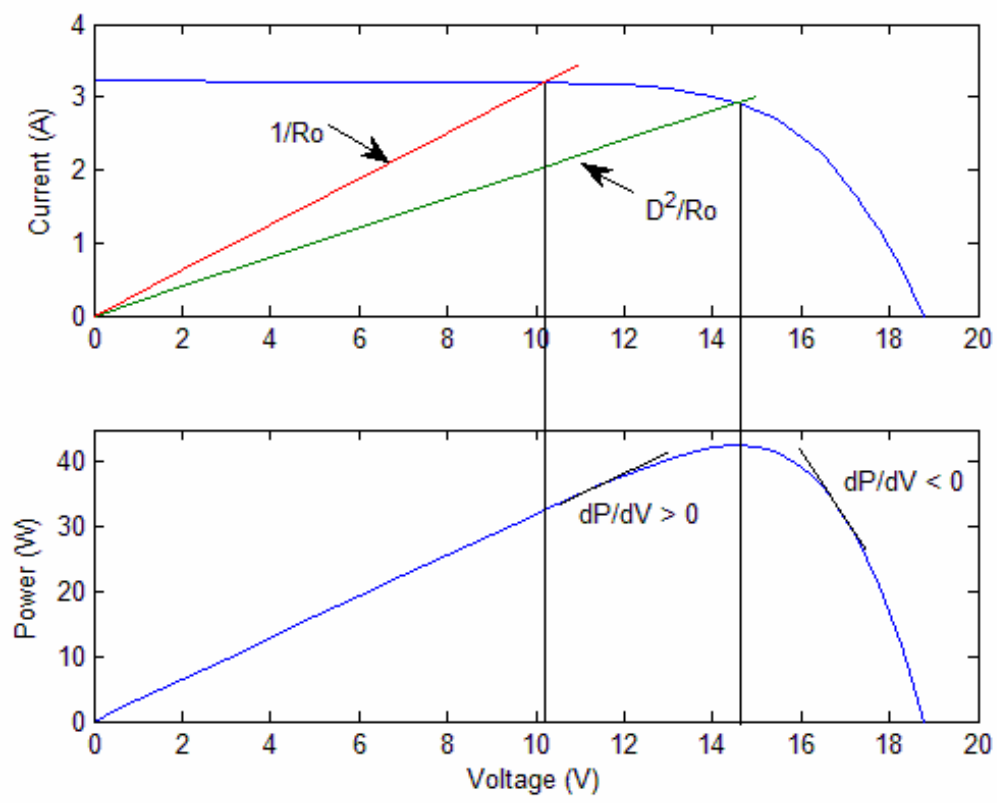

Figure (6): DC/DC converter helps in tracking the peak power point. 


\section{$\underline{\text { 4.MPPT Techniques }}$}

\subsection{Hill Climbing/P\&O}

Hill climbing involves a perturbation in the duty ratio of the power converter according to the sign of $\mathrm{dP} / \mathrm{dV}$ [4-10]. The flow chart of the algorithm is shown in Fig.7.

As illustrated in Fig.6, in the right hand side curve where the voltage is almost constant the slope of power voltage is negative $(\mathrm{dP} / \mathrm{dV}<0)$ whereas in the left hand side, the slope is positive $(\mathrm{dP} / \mathrm{dV}>0)$. The right side curve is for the lower duty cycle (nearer to zero) whereas the left side curve is for the higher duty cycle (nearer to unity). So, depending on the sign of $\mathrm{dP}(\mathrm{P}(\mathrm{k}+1)-\mathrm{P}(\mathrm{k}))$ and $\mathrm{dV}(\mathrm{V}(\mathrm{k}+1)-\mathrm{V}(\mathrm{k}))$ the algorithm decides whether to increase or reduce the duty cycle until to reach the MPP.

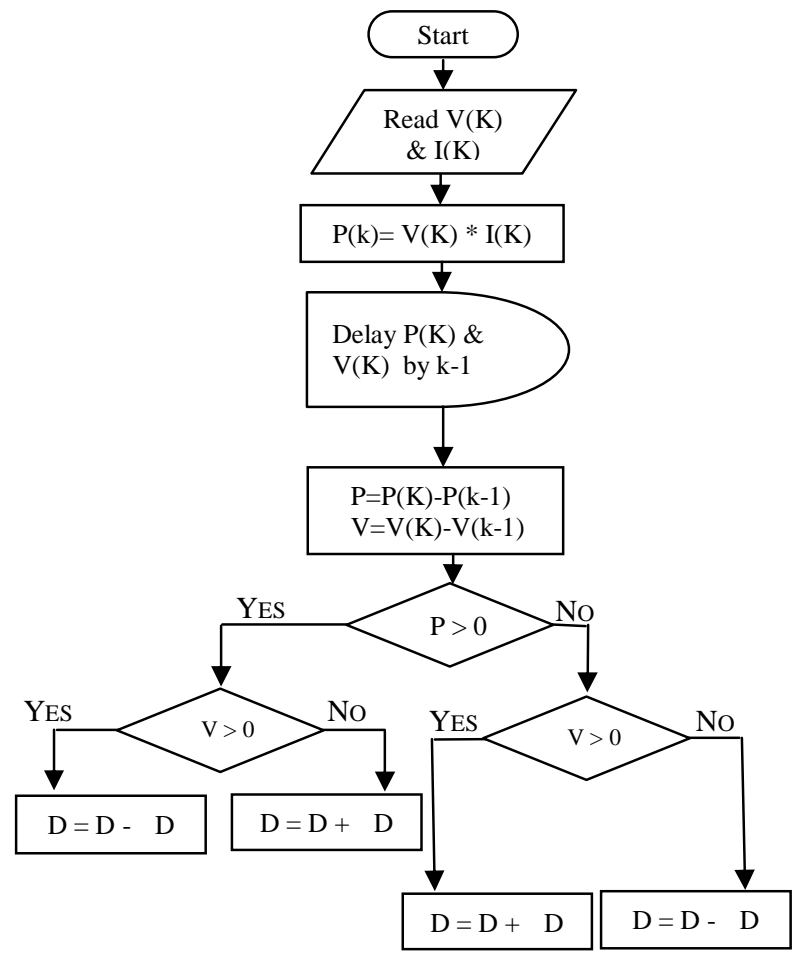

Figure (7): Hill Climbing/Perturb and observe MPPT flowchart used for Matlab simulation

Results for implementing such algorithm for the polycrystalline type are shown in Fig.8 (a) \& (b) starting from higher duty cycle (left half of the PV curve) that is 0.96 and at 0.59 initial duty cycle value which lies in the right half of the PV curve. In such cases, solar insolation and cell temperature were kept constant at $\mathrm{S}=715.8 \mathrm{~W} / \mathrm{m} 2, \mathrm{~T}=50.1^{\circ} \mathrm{C}$. From the achieved results, it is inferred that the algorithm tracks the peak power from both directions of PV curve (right and the left halves), and then system oscillates about the MPP. The oscillation lies between three points $-2 \%$ maximum of the MPP for a 
constant perturbation $\mathrm{D}=0.04$. The oscillation can be minimized by reducing the perturbation step size. However, a smaller perturbation size slows down tracking MPPT. A solution to this conflicting situation is to have a variable perturbation size that gets smaller towards the MPP as shown in [4-5]. In [6], fuzzy logic control is used to optimize the magnitude of the next perturbation. In [7], a two-stage algorithm is proposed that offers faster tracking in the first stage and finer tracking in the second stage.

Two sensors are usually required to measure the PV array voltage and current from which power is computed, but depending on the power converter topology, only a voltage sensor might be needed as in [8]. In [9], the PV array current from the PV array voltage is estimated, eliminating the need for a current sensor. Digital signal processing (DSP) or microcomputer control is more suitable for hill climbing and $\mathrm{P} \& \mathrm{O}$ even though discrete analog and digital circuitry can be used as in [10].
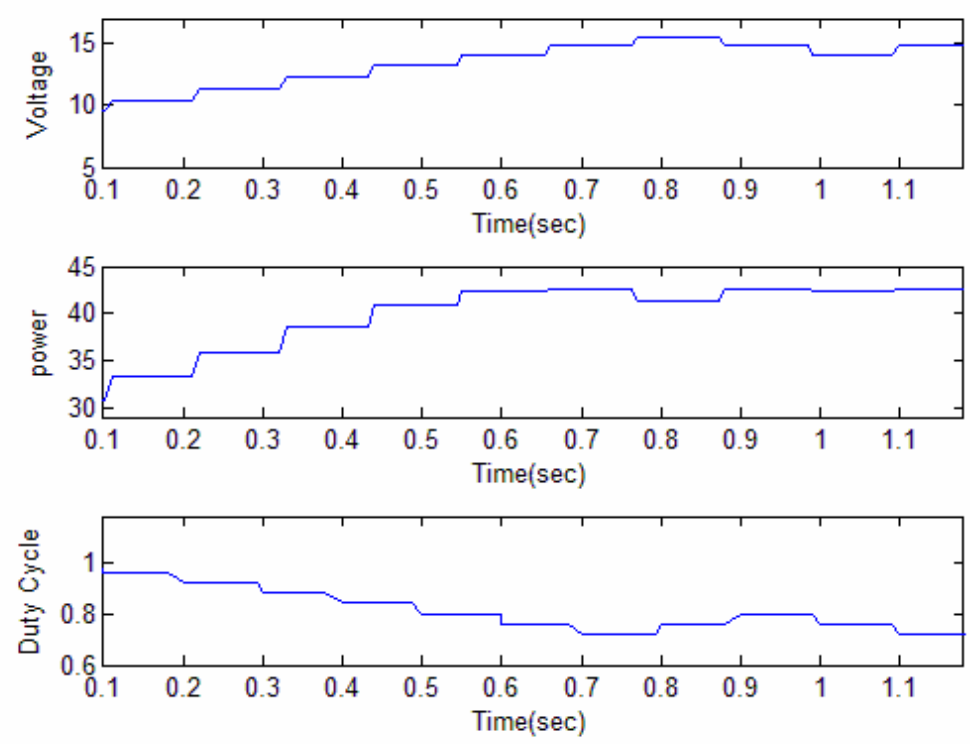

Figure (8a): Hill Climbing/Perturb and observe MPPT algorithm for the polycrystalline type from the left half of the PV curve 

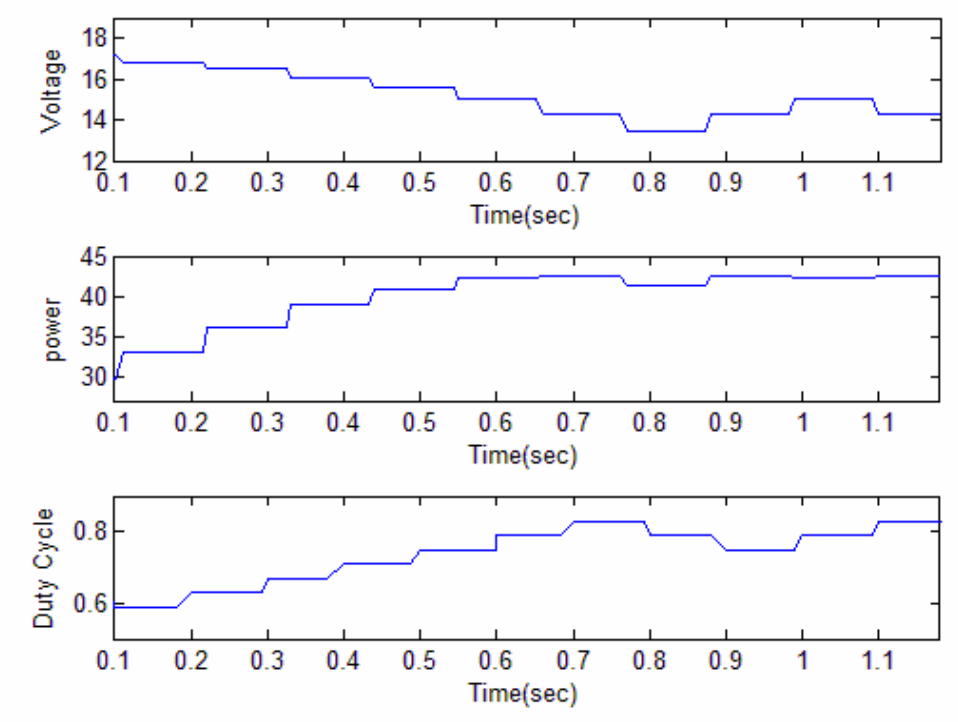

Figure (8b): Hill Climbing/Perturb and observe MPPT algorithm for the polycrystalline type from right half of the PV curve.

\subsection{Incremental Conductance}

The incremental conductance (IncCond) method is based on the slope of the PV array power curve [11]:

$\left\{\begin{array}{l}\frac{d P}{d V}=0, \text { at MPP } \\ \frac{d P}{d V}>0, \text { left of MPP } \\ \frac{d P}{d V}<0, \text { right of MPP }\end{array}\right\}$

Since $\frac{\mathrm{dP}}{\mathrm{dV}}=\frac{\mathrm{d}(\mathrm{IV})}{\mathrm{dV}}=\mathrm{I}+\mathrm{V} \frac{\mathrm{dI}}{\mathrm{dV}} \cong \mathrm{I}+\mathrm{V} \frac{\Delta \mathrm{I}}{\Delta \mathrm{V}}$

Equation (9) Can be rewritten as:

$$
\left\{\begin{array}{l}
\frac{\Delta \mathrm{I}}{\Delta \mathrm{V}}=-\frac{\mathrm{I}}{\mathrm{V}}, \text { at MPP } \\
\frac{\Delta \mathrm{I}}{\Delta \mathrm{V}}>-\frac{\mathrm{I}}{\mathrm{V}}, \text { left of MPP } \\
\frac{\Delta \mathrm{I}}{\Delta \mathrm{V}}<-\frac{\mathrm{I}}{\mathrm{V}}, \text { right of MPP }
\end{array}\right\}
$$


Thus, MPP can be tracked by comparing the instantaneous conductance (I/V) to the incremental conductance ( $\mathrm{I} / \mathrm{V}$ ) as shown in the flowchart illustrated in Fig. 9. The algorithm decrements or increments the duty Cycle to track the new MPP. The increment size determines how fast the MPP is tracked.

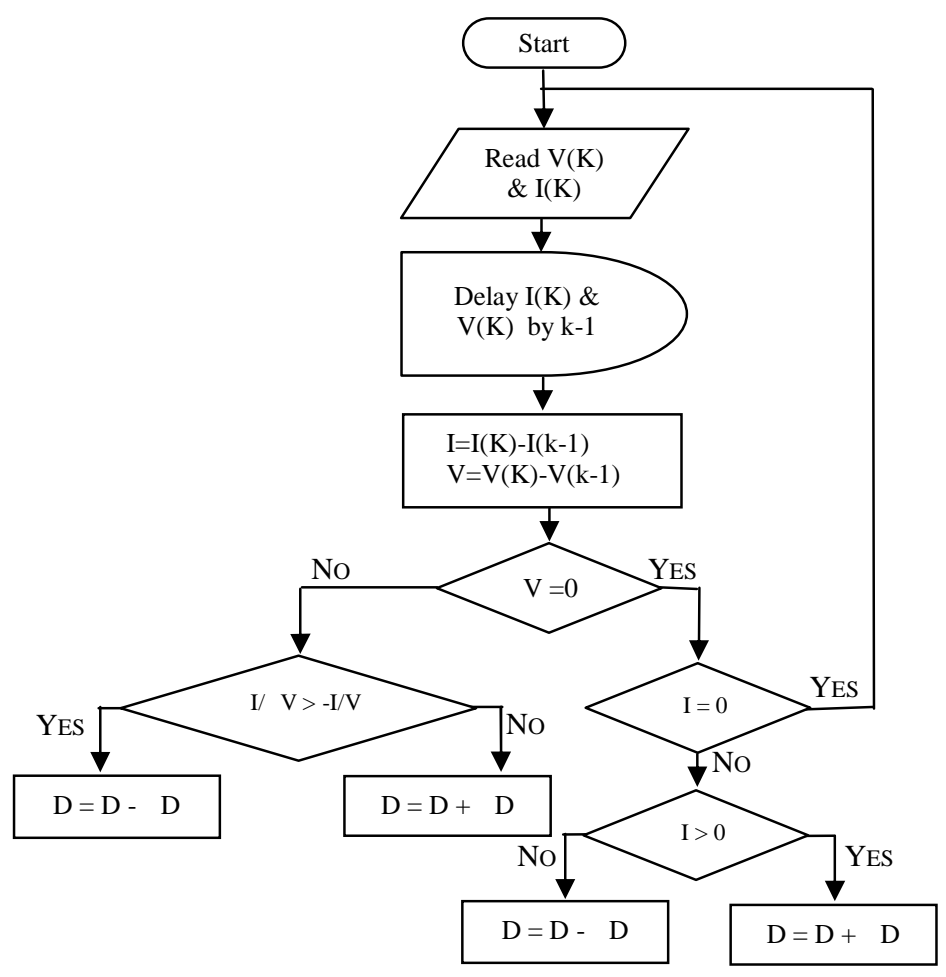

Figure (9): IncCond flowchart

Results for implementing such algorithm for the single-crystalline are shown in Fig.10 (a) $\&$ (b) starting from higher duty cycle (left half of the PV curve) that is 0.96 and at 0.59 initial duty cycle value which lies in the right half of the PV curve. In such cases, solar insolation and cell temperature were kept constant at $\mathrm{S}=715.8 \mathrm{~W} / \mathrm{m} 2, \mathrm{~T}=50.1^{\circ} \mathrm{C}$.

The system then oscillates about MPP. The oscillation is between three points $-1.4 \%$ maximum of the MPP for a constant perturbation $\mathrm{D}=0.04$.

In [11], a method is proposed that brings the operating point of the PV array close to the MPP in a first stage and then uses IncCond to exactly track the MPP in a second stage. By proper control of the power converter, the initial operating point is set to match a load resistance proportional to the ratio of the open-circuit voltage (VOC) to the short-circuit current (ISC) of the PV array. This two-stage alternative also ensures that the real MPP is tracked in case of multiple local maxima. 

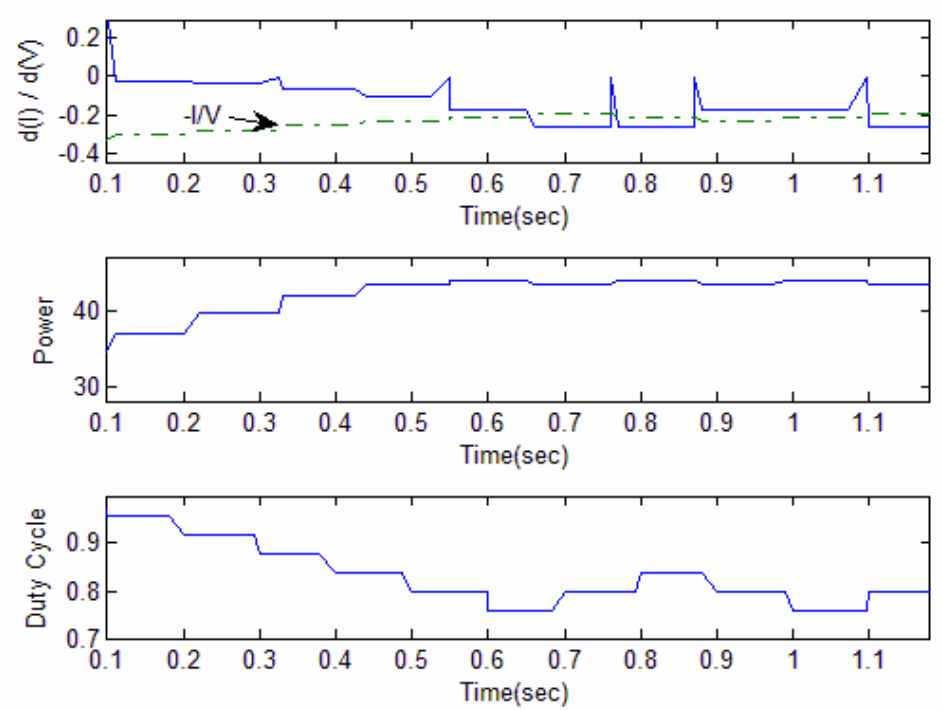

Figure (10a): IncCond MPPT algorithm for single-crystalline from the Left half of the PV curve
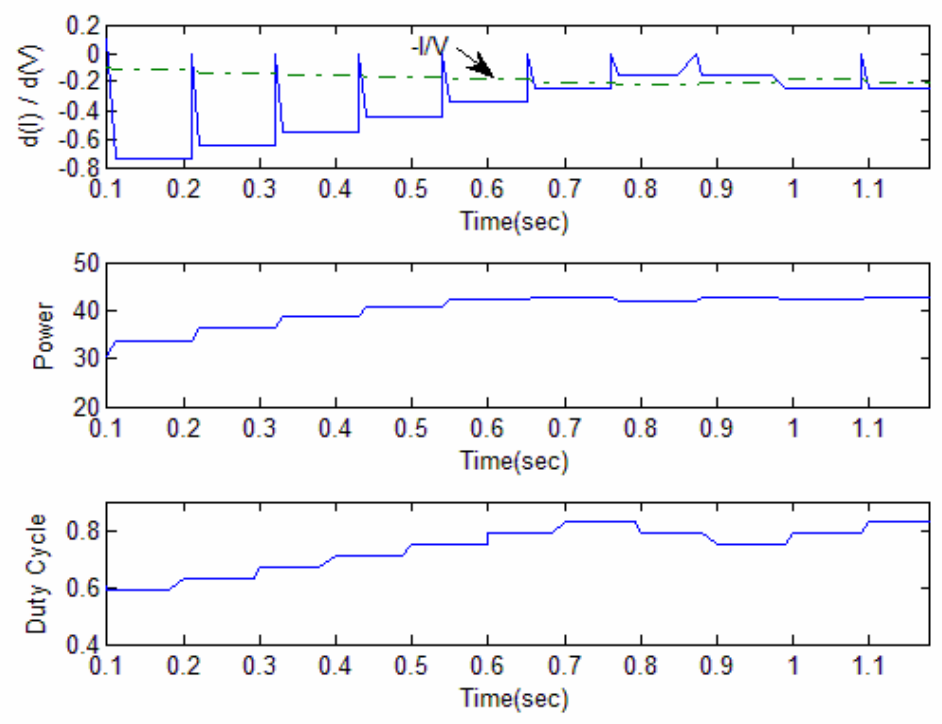

Fig. 10 (b)

Figure (10b): IncCond MPPT algorithm for single-crystalline from the Right half of the PV curve

Measurements of the instantaneous PV array voltage and current require two sensors. IncCond method lends itself well to DSP and microcontroller control, which can easily keep track of previous values of voltage and current and make all the decisions as per Fig.9. 


\subsection{Fractional Open-Circuit Voltage}

The near linear relationship between $\mathrm{V}_{\mathrm{MPP}}$ and $\mathrm{V}_{\mathrm{OC}}$ of the PV array, under varying irradiance and temperature levels, has given rise to the fractional $\mathrm{V}_{\mathrm{OC}}$ method [12-14].

$\mathrm{V}_{\mathrm{MPP}} \approx \mathrm{K}_{1} * \mathrm{~V}_{\mathrm{OC}}$

Where $K_{1}$ is a constant of proportionality which dependent on the characteristics of the PV array being used. It is usually has to be computed beforehand by empirically determining $\mathrm{V}_{\mathrm{MPP}}$ and $\mathrm{V}_{\mathrm{OC}}$ for a specific $\mathrm{PV}$ array at different irradiance and temperature levels. The factor $\mathrm{K}_{1}$ has been reported to be between 0.71 and 0.78 .

The algorithm of the fractional open circuit voltage is presented in Fig.11. The duty cycle is reduced or increased by comparing $\mathrm{V}_{\mathrm{MPP}}$ computed from $\mathrm{V}_{\mathrm{OC}}$ and the actual voltage $\mathrm{V}_{\text {act}}$.

At $\mathrm{S}=715.8 \mathrm{~W} / \mathrm{m}^{2}, \mathrm{~T}=50.1^{\circ} \mathrm{C}, \mathrm{K}_{1}=0.7754$ for the polycrystalline type, 0.7671 for the single-crystalline type and 0.7076 for the amorphous type.

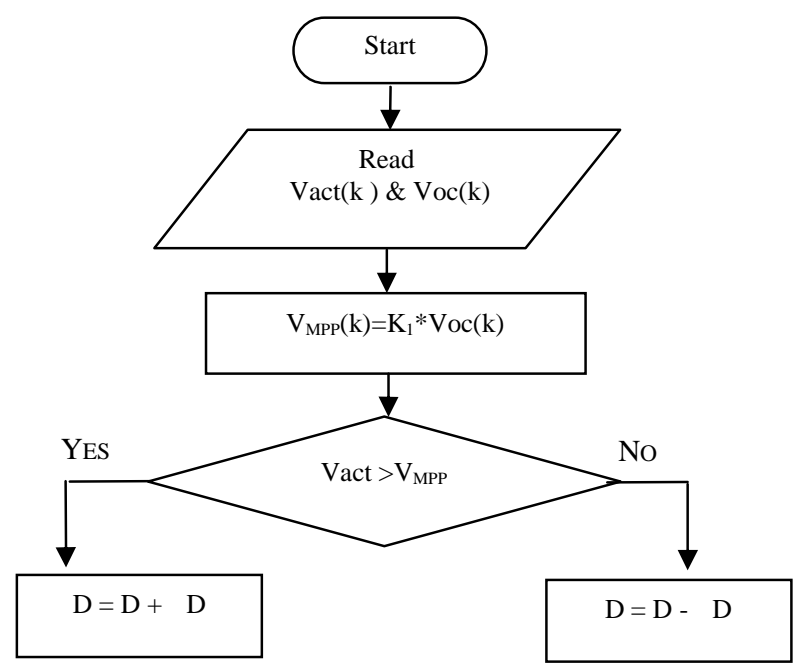

Figure (11): Fractional Open-circuit Voltage algorithm

From Figs. 12 (a) \& (b), it is clear that the algorithm tracks the peak power and also from both the directions of the PV curve (right half and the left half) at $\mathrm{S}=715.8 \mathrm{~W} / \mathrm{m}^{2}$, $\mathrm{T}=50.1^{\circ} \mathrm{C}$ for the amorphous type. 

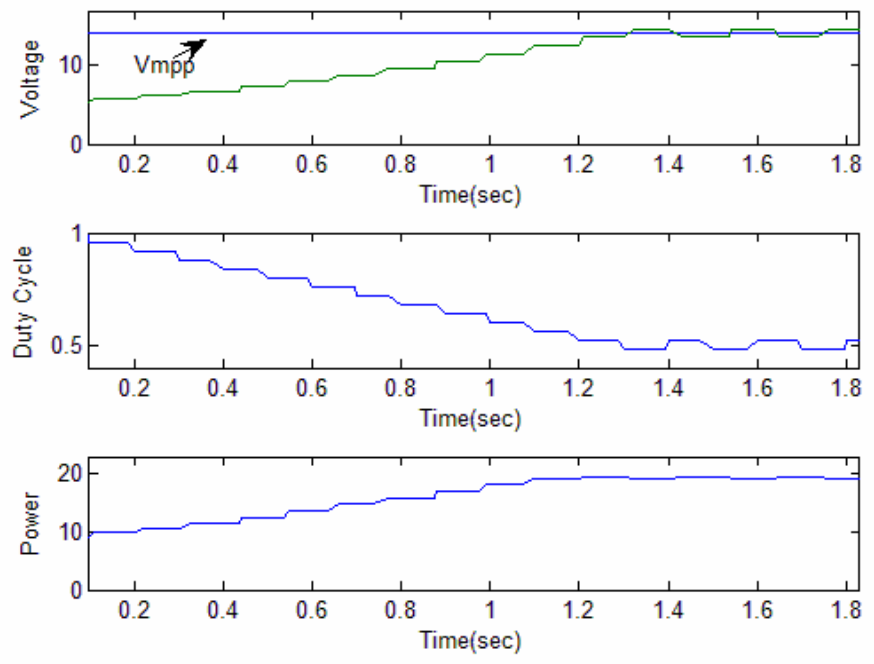

Figure (12a): Fractional open-circuit voltage MPPT from the left half
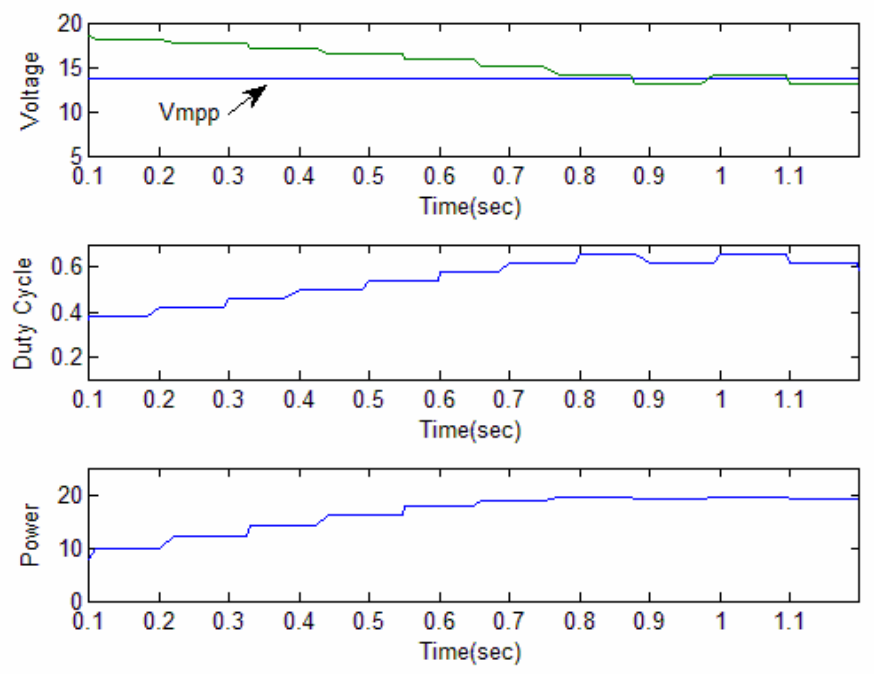

Figure (12b): Fractional open-circuit voltage MPPT from the right half

The oscillation is between two points $-1.2 \%$ maximum of the MPP for a constant perturbation $\mathrm{D}=0.04$. From the left half, the system takes more time response to reach the MPP; due to the duty cycle at which the MPP occurs of the amorphous type is far from the initial duty cycle 0.96 .

Once $\mathrm{K}_{1}$ is known, $\mathrm{V}_{\mathrm{MPP}}$ can be computed using (12) with $\mathrm{V}_{\mathrm{OC}}$ measured periodically by momentarily shutting down the power converter. However, this incurs some disadvantages, including temporary loss of power. To prevent this, [12] uses pilot cells from which $\mathrm{V}_{\mathrm{OC}}$ can be obtained. These pilot cells must be carefully chosen to closely represent the characteristics of the PV array. In [13], it is claimed that the voltage 
generated by $\mathrm{PN}$-junction diodes is approximately $75 \%$ of $\mathrm{V}_{\mathrm{OC}}$. This eliminates the need for measuring $\mathrm{V}_{\mathrm{OC}}$ and computing $\mathrm{V}_{\mathrm{MPP}}$.

Since (12) is only an approximation, the PV array technically never operates at the MPP. Depending on the application of the PV system, this can sometimes be adequate. Even if fractional $\mathrm{V}_{\mathrm{OC}}$ is not a true MPPT technique, it is very easy and cheap to implement as it does not necessarily require DSP or microcontroller control. However, [14] points out that $\mathrm{k}_{1}$ is no more valid in the presence of partial shading (which causes multiple local maxima) of the PV array and proposes sweeping the PV array voltage to update $\mathrm{K}_{1}$. This obviously adds to the implementation complexity and incurs more power loss.

\subsection{Fractional Short-Circuit current}

Fractional $\mathrm{I}_{\mathrm{SC}}$ results from the fact that, under varying atmospheric conditions, $\mathrm{I}_{\mathrm{MPP}}$ is approximately linearly related to the $\mathrm{I}_{\mathrm{SC}}$ of the PV array as shown in [14-15]

$\mathrm{I}_{\mathrm{MPP}} \approx \mathrm{K}_{2} * \mathrm{I}_{\mathrm{SC}}$

Where $\mathrm{K}_{2}$ is a constant of proportionality as in the fractional $\mathrm{V}_{\mathrm{OC}}$ technique, $\mathrm{K}_{2}$ has to be determined according to the PV array in use. The constant $\mathrm{K}_{2}$ is generally found to be between 0.78 and 0.92

At $\mathrm{S}=715.8 \mathrm{~W} / \mathrm{m}^{2}, \mathrm{~T}=50.1^{\circ} \mathrm{C} \mathrm{K}_{2}=0.9084$ for the polycrystalline, 0.8883 for the singlecrystalline and 0.7845 for the amorphous type.

The algorithm of the fractional short circuit current is presented in Fig.13. The duty cycle is reduced or increased by comparing $\mathrm{I}_{\mathrm{MPP}}$ computed from $\mathrm{I}_{\mathrm{SC}}$ and the actual current $\mathrm{I}_{\mathrm{act}}$.

Fig.14 (a) \& (b) represent the duty cycle produced by comparing $\mathrm{I}_{\mathrm{MPP}}$ computed from $\mathrm{I}_{\mathrm{SC}}$ and the actual current $\mathrm{I}_{\text {act }}$ at $\mathrm{S}=715.8 \mathrm{~W} / \mathrm{m}^{2}, \mathrm{~T}=50.1^{\circ} \mathrm{C}$ for the polycrystalline type.

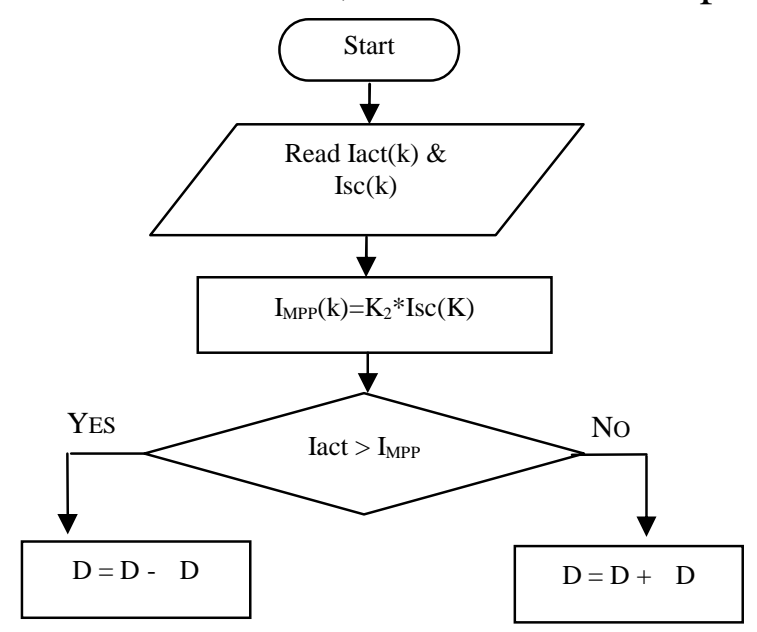

Figure (13): Fractional Short-Circuit current algorithm 

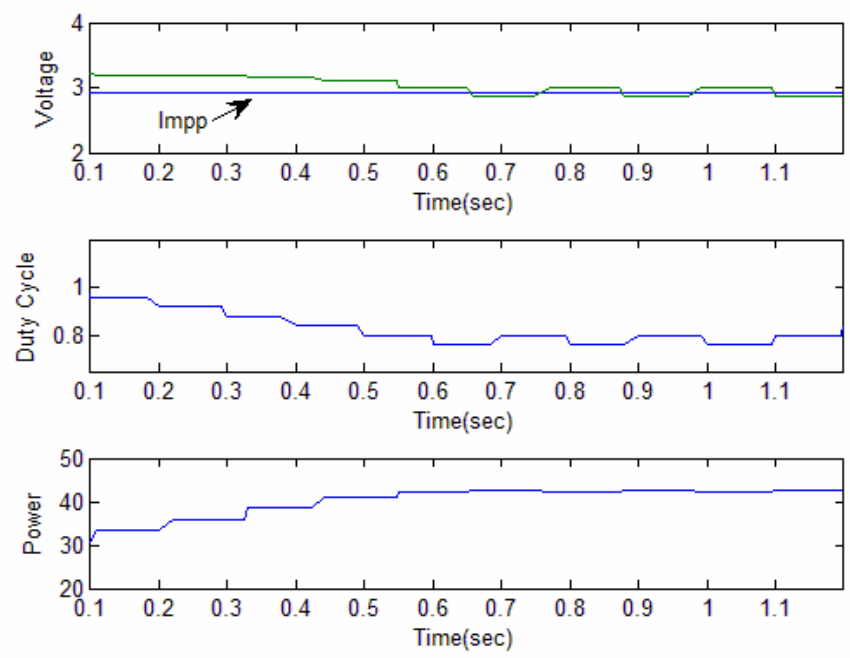

Figure (14a): Left half of Fractional Short-Circuit current for the polycrystalline type
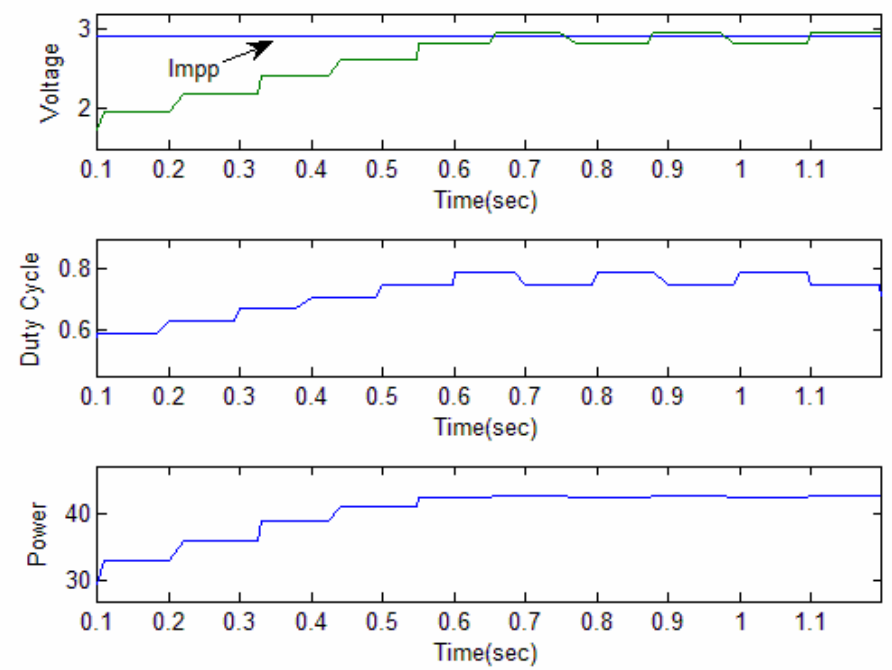

Figure (14b): Right half of Fractional Short-Circuit current for the polycrystalline type.

The oscillation is between two points $-0.6 \%$ maximum of the MPP for a constant perturbation $\mathrm{D}=0.04$.

Measuring $\mathrm{I}_{\mathrm{SC}}$ during operation is problematic. An additional switch usually has to be added to the power converter to periodically short the PV array so that $\mathrm{I}_{\mathrm{SC}}$ can be measured using a current sensor. This increases the number of components and cost. In [15], a boost converter is used, where the switch in the converter itself can be used to short the PV array. 


\section{MPP Tracking Efficiency}

The tracking efficiency is defined as in [16]:

$\eta=\frac{1}{\mathrm{n}} \sum_{\mathrm{i}=1}^{\mathrm{n}} \frac{\mathrm{P}_{\mathrm{i}}}{\mathrm{P}_{\max , \mathrm{i}}}$

Where $\mathrm{P}_{\mathrm{i}}$ represents the $\mathrm{PV}$ modules' output power, $\mathrm{P}_{\text {max, }}$ represents the maximum power available at the PV modules and $\mathrm{n}$ is the number of samples.

Fig.15 represents the tacking efficiency of the single-crystalline, polycrystalline and amorphous. The oscillations around the MPP are completely eliminated for various irradiations at constant cell temperature $\mathrm{T}=50.1^{\circ} \mathrm{C}$. As shown, single-crystalline and polycrystalline types have better tacking efficiency than amorphous type.

For the four methods of MPPT, there is no difference in their tracking efficiency since the initial duty cycle D and the increment size D are the same and the oscillations around the MPP are completely eliminated.

A comparison for the cost of polycrystalline and amorphous in is listed in Table 2. As noticed, the unit price of the polycrystalline is approximately 1.32 of the amorphous price.

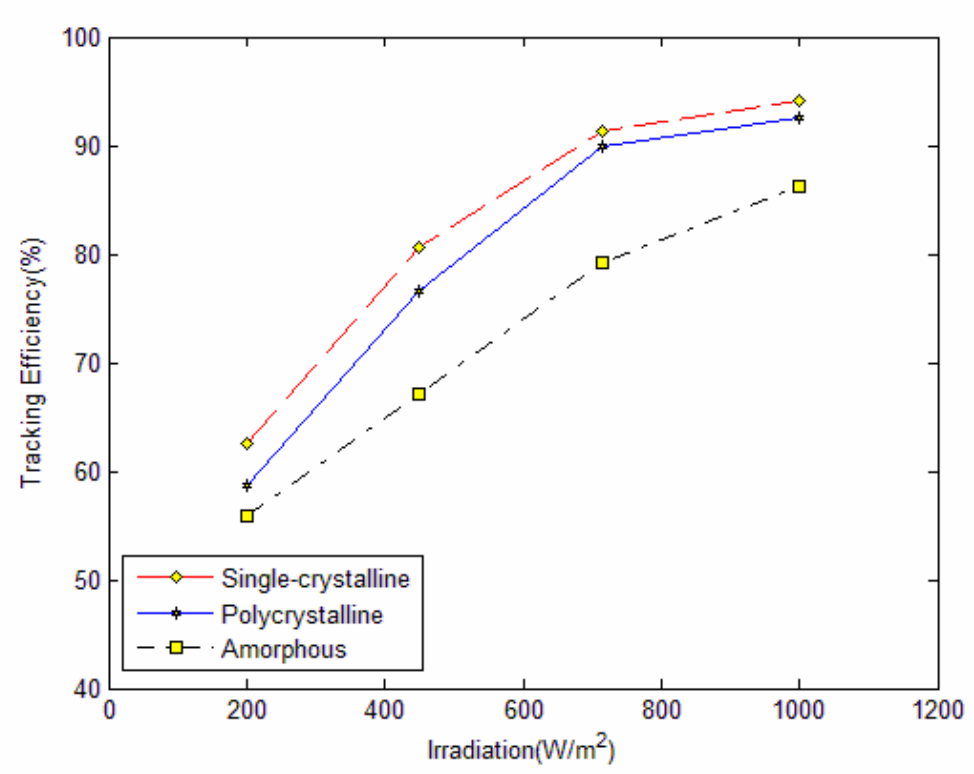

Figure (15): Tracking efficiency at $T=50.1^{\circ} \mathrm{C}$ 
Table (2): Cost of polycrystalline and amorphous types

\begin{tabular}{|l|c|c|c|c|c|}
\hline Silicone type & Type & $\begin{array}{c}\text { Output } \\
\text { Power }\end{array}$ & $\begin{array}{c}\text { Roof } \\
\text { Area }\end{array}$ & $\begin{array}{c}\text { Total } \\
\text { price }\end{array}$ & Unit price \\
\hline Amorphous & $\begin{array}{c}60 \mathrm{MST}-43, \\
43-\mathrm{watt}\end{array}$ & $\begin{array}{c}2580 \\
\text { watts }\end{array}$ & 517 sq. $\mathrm{ft}$ & $\$ 11,250.00$ & $\$ 4.36 / \mathrm{watt}$ \\
\hline Polycrystalline & $\begin{array}{c}24 \mathrm{MSX}-120, \\
120-\mathrm{watt}\end{array}$ & $\begin{array}{c}2880 \\
\text { watts }\end{array}$ & $288 \mathrm{sq} . \mathrm{ft}$ & $\$ 16,527.00$ & $\$ 5.74 / \mathrm{watt}$ \\
\hline
\end{tabular}

\section{Performance at a sudden climatic change}

When the radiation increases suddenly from 450 to $715.8 \mathrm{~W} / \mathrm{m}^{2}$ for the single-crystalline type, the system presents a good performance and tracks the new MPPT with 92\% tracking efficiency as shown in Fig.16.

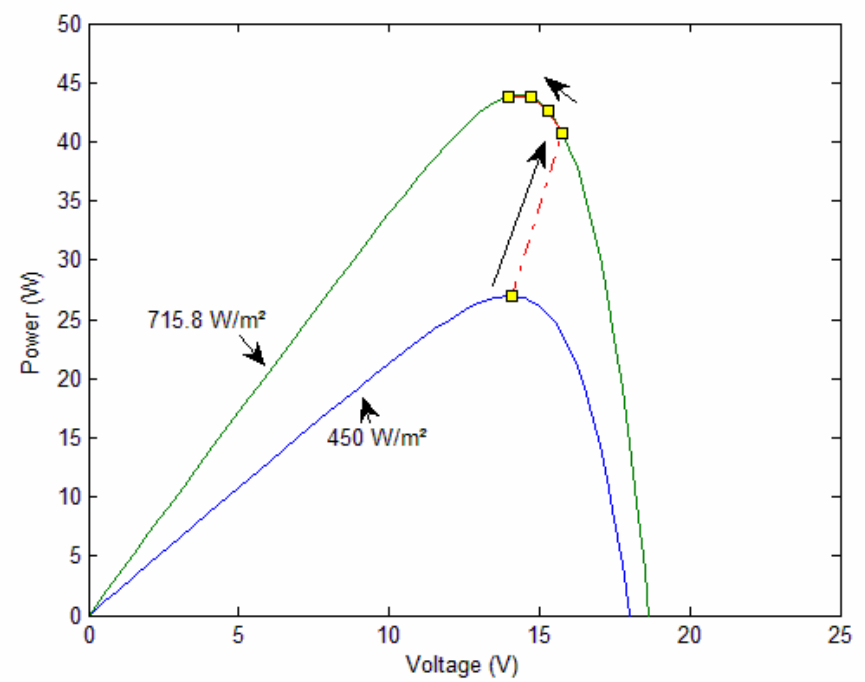

Figure (16): Tracking new MPP when solar radiation changes

\section{Major characteristics of MPPT techniques}

The major characteristics of the four studied MPPT techniques that must be taken into consideration to choose which one is better according to applications needs are highlighted in Table 3. Concerning economic cost, a good cost comparison can be made by knowing whether the technique is analog or digital, whether it requires software and programming, and the number of sensors. Analog implementation is generally cheaper than digital, which normally involves a microcontroller that needs to be programmed. Eliminating current sensors considerably drops the costs.

\section{$\underline{\text { 8. Conclusion }}$}

This paper presents a comparative study of four most commonly used methods, low-cost 
implementations: Hill Climbing/the perturb and observe (P\&O), Incremental Conductance, Fractional Open-Circuit Voltage and Fractional Short-Circuit Current maximum power point tracking algorithms. Models of different Types of photovoltaic are implemented such as single-crystalline, polycrystalline and amorphous. The tracking efficiency of each PV model is represented at various climatic conditions.

Table (3): Major characteristics of the four studied MPPT techniques

\begin{tabular}{|c|c|c|c|c|}
\hline MPPT techniques & Hill Climbing/P\&O & $\begin{array}{l}\text { Incremental } \\
\text { Conductance }\end{array}$ & $\begin{array}{l}\text { Fractional Open-Circuit } \\
\text { Voltage }\end{array}$ & $\begin{array}{c}\text { Fractional Short-Circuit } \\
\text { Current }\end{array}$ \\
\hline PV array dependent & No & No & Yes $\left(\mathrm{K}_{1}=0.71-0.78\right)$ & Yes $\left(\mathrm{K}_{2}=0.78-0.92\right)$ \\
\hline $\begin{array}{l}\text { Tracking true MPP continuously } \\
\text { or an approximation }\end{array}$ & $\begin{array}{l}\text { Continuously tracks } \\
\text { the true MPP }\end{array}$ & $\begin{array}{l}\text { Continuously tracks } \\
\text { the true MPP }\end{array}$ & Approximation ,not true MPP & Approximation , not true MPP \\
\hline Periodic tuning & $\begin{array}{l}\text { Does not require } \\
\text { periodic tuning }\end{array}$ & $\begin{array}{l}\text { Does not require } \\
\text { periodic tuning }\end{array}$ & $\begin{array}{l}\text { Requires periodic tuning, } \\
\text { ( Less reliable ) }\end{array}$ & $\begin{array}{l}\text { Requires periodic tuning, } \\
\text { ( Less reliable ) }\end{array}$ \\
\hline Convergence Speed & varies & varies & Medium & Medium \\
\hline Implementation complexity & Low & Medium & Low & Medium \\
\hline Parameters & Voltage, current & Voltage, current & Voltage & Current \\
\hline Analog or digital implementation & Both & Digital & Both & Both \\
\hline $\begin{array}{l}\text { Require the using software and } \\
\text { programming }\end{array}$ & $\begin{array}{l}\text { Yes (familiar with } \\
\text { Digital circuit) }\end{array}$ & $\begin{array}{l}\text { Yes (familiar with } \\
\text { Digital circuit) }\end{array}$ & $\begin{array}{l}\text { No (familiar with Analog } \\
\text { circuit) }\end{array}$ & $\begin{array}{l}\text { No (familiar with Analog } \\
\text { circuit) }\end{array}$ \\
\hline Sensors used & $\begin{array}{l}\text { Only a voltage sensor } \\
\text { might be needed and } \\
\text { current is estimated. }\end{array}$ & $\begin{array}{l}\text { Only a voltage sensor } \\
\text { might be needed and } \\
\text { current is estimated. }\end{array}$ & $\begin{array}{l}\text { It is easier and more reliable } \\
\text { to measure voltage than } \\
\text { current. }\end{array}$ & $\begin{array}{l}\text { Current sensors are usually } \\
\text { expensive and bulky. }\end{array}$ \\
\hline
\end{tabular}

References:

[1] Trishan Esram, and Patrick L. Chapman, "Comparison of Photovoltaic Array Maximum Power Point Tracking Techniques", IEEE Trans. Energy Conversion, Vol. 22, No. 2, June 2007.

[2] T. Ikegami, T. Maezono, F. Nakanishi, Y. Yamagata, K. Ebihara, "Estimation of equivalent circuit parameters of PV module and its application to optimal operation of PV system", Solar Energy Materials \& Solar Cells (2001), pp. 389-395.

[3] Francisco M. González-Longatt, "Model of Photovoltaic Module in Matlab", II CIBELEC 2005.

[4]W. Xiao and W. G. Dunford, "A modified adaptive hill climbing MPPT method for photovoltaic power systems," Proc. $35^{\text {th }}$ Annual IEEE Power Electron. Spec. Conf., 2004, pp. 1957-1963.

[5] N. Femia, G. Petrone, G. Spagnuolo, and M. Vitelli, "Optimization of perturb and observe maximum power point tracking method," IEEE Trans. Power Electron, Vol. 20, no. 4, pp. 963-973, July 2005.

[6] N. S. D'Souza, L. A. C. Lopes, and X. Liu, "An intelligent maximum power point tracker using peak current control," in Proc. $36^{\text {th }}$ Annual IEEE Power Electron Spec. Conf., 2005, pp. 172-177.

[7] S. Jain and V. Agarwal, "A new algorithm for rapid tracking of approximate maximum power point in photovoltaic systems," IEEE Power Electron. Vol. 2, no. 1, pp. 16-19, Mar. 2004.

[8] P. J. Wolfs and L. Tang, "A single cell maximum power point tracking converter 
without a current sensor for high performance vehicle solar arrays," in Proc. $36^{\text {th }}$ Annual IEEE Power Electron. Spec. Conf., 2005, pp. 165-171.

[9] N. Kasa, T. Iida, and L. Chen, "Fly back inverter controlled by sensor less current MPPT for photovoltaic power system," IEEE Trans. Ind. Electron, Vol. 52, no. 4, pp. 1145-1152, Aug. 2005.

[10]Y. Kim, H. Jo, and D. Kim, "A new peak power tracker for cost-effective photovoltaic power system," in Proc. 31st Intersociety Energy Convers. Eng. Conf., 1996, pp. 1673-1678.

[11] K. Irisawa, T. Saito, I. Takano, and Y. Sawada, "Maximum power point tracking control of photovoltaic generation system under non-uniform insolation by means of monitoring cells," in Conf. Record Twenty-Eighth IEEE Photovoltaic Spec. Conf., 2000, pp. 1707-1710.

[12] G. W. Hart, and C. H. Cox, "Experimental tests of open loop maximum-power-point tracking techniques", Solar Cells, vol. 13, pp. 185-195, 1984.

[13] K. Kobayashi, H. Matsuo, and Y. Sekine, "A novel optimum operating point tracker of the solar cell power supply system," in Proc. $35^{\text {th }}$ Annual IEEE Power Electron. Spec. Conf., 2004, pp. 2147-2151.

[14] B. Bekker and H. J. Beukes, "Finding an optimal PV panel maximum power point tracking method," in Proc. 7th Africon Conf. Africa, 2004, pp. 1125-1129.

[15] S. Yuvarajan and S. Xu, "Photovoltaic power converter with a simple maximum power point tracker," in Proc. 2003 Int. Symp. Circuits Syst., 2003, pp. III-399-III-402.

[16] T. Tafticht, K. Agbossou_, M.L. Doumbia, A. Che' riti, "An improved maximum power point tracking method for photovoltaic systems", 15 August 2007.

\section{Nomenclatures:}

\begin{tabular}{|c|c|}
\hline $\mathrm{I}_{0} \ldots$ & Diode saturation current \\
\hline$I_{d} \ldots$ & Diode current or (dark current) \\
\hline $\mathrm{I}_{\mathrm{do}} \ldots$ & Diode reversal current \\
\hline $\mathrm{I}_{\mathrm{MPP}} \ldots$ & Maximum Power Point Current \\
\hline IncCond... & Incremental Conductance \\
\hline $\mathrm{I}_{\mathrm{ph}} \ldots$ & Photo current \\
\hline $\mathrm{I}_{\mathrm{SC}} \ldots$ & Short-Circuit Current \\
\hline $\mathrm{I}_{\text {sho }} \ldots$ & Short-circuit current at reference state \\
\hline $\mathrm{J}_{0} \ldots$ & Temperature Coefficient \\
\hline $\mathrm{K} \ldots$ & Boltzmann constant \\
\hline $\mathrm{K}_{1} \ldots$ & Constant of proportionality of the Fractional Open-Circuit Voltage \\
\hline $\mathrm{K}_{2} \ldots$ & Constant of proportionality of the Fractional Short-Circuit current \\
\hline$\eta$ & Tracking efficiency \\
\hline
\end{tabular}

